\title{
The Influence of Debt to Equity Ratio, Return on Equity and Price Earning Ratio Towards Mining Company Value Listed in Indonesian Stock Exchange for the Period 2014-2018
}

\author{
Sri Wahyuni, Evi Irwan Sari Br Sianturi², Dina Ria Restu Uli P³, Fuji Astuty \\ 1,2,3,4 Department of Accounting, Faculty of Economics, Universitas Prima Indonesia, Indonesia
}

Abstract

The purpose of this research is to analyze and determine the effect of the effect of Debt to Equity Ratio, ROE and Price Earning Ratio on firm value in mining companies listed on the Indonesia Stock Exchange 2014-2018 period. This study uses a quantitative approach, this type of research is causal and deductive in nature. The sampling technique used a purposive sampling method. The study population was 44 companies and the sample used was 17 mining companies listed on the Indonesia Stock Exchange for the period 2014-2018. The data analysis technique used multiple regression tests and classical assumptions. The test results show ROE and PER have a significant positive effect on firm value, DER has no effect on firm value. DER, ROE and PER affect the value of the company in mining companies listed on the Indonesia Stock Exchange for the period $2014-2018$ only $16.5 \%$.

\section{INTRODUCTION}

Firm value is the investor's perception of the company's success rate, which is often associated with stock prices. The high share price certainly makes the company value increase. The main objective of the company is to maximize the company's wealth or value.

Debt to equity ratio analysis is often used to determine each rupiah of own capital that is used as collateral for debt. An increase in DER means an increase in the interest expense borne by the company. With the increase in DER, the company's profit has decreased. Therefore, the higher the DER of a company, it will make investors very careful in considering their investments, thus lowering the company's value.

The higher the Return On Equity, the higher the rate of return on investment from the results of the company's equity in gaining profits from the equity owned by the company. On the other hand, the existence of company efficiency in using company profits or profits can be a positive signal for investors, in order to accrue company value through its share price.

Price Earning Ratio can be used to measure how investors assess future growth prospects which are reflected in the stock price that investors are willing to pay for every rupiah of profit the company receives. So that the higher the PER, the better the prospect of the company as seen from the earnings generated so that the higher the company value.

This research was conducted in the mining sector because this sector has to incur increasingly expensive rents for mining land. The land used for mining is state-owned land and the government has also set export regulations for mining products which are intended to prevent illegal transactions so that mineral supplies in Indonesia do not run out quickly. In other words, on the one hand the company has a large amount of costs to be paid so that the company has to increase its sales, but the products to be sold are limited by the government. The mining sector on the IDX are 44 issuers. The IDX is a means of bringing together share sale and purchase offers that companies can use to obtain additional funds as capital.

This study aims to analyze and determine the effect of the Debt to Equity Ratio, Return on Equity and Price Earning Ratio on company value at mining companies listed on the Indonesia Stock Exchange for the period 2014-2018. 


\section{Debt to Equity Ratio}

According to (Utami \& Welas, 2019) DER is used to find out the amount of funds provided by the borrower (creditor) and the company owner. According to (Jusuf, 2016), in general it can be said that the higher this ratio, the greater the risk of creditors (including banks). DER greater than 1 (one) indicates that the source of company asset financing comes more from debt than equity.

According to (Anggriawan, Topowijono, \& Sudjana, 2017) DER can be calculated using the formula:

$$
\text { DER }=\frac{\text { Total Debt }}{\text { Total Equity }}
$$

\section{Return on Equity}

According to (Hidayat, 2019) ROE is a measure of a company's earnings (profits) relative to the invested capital. According to (Setiawanta, 2016), the higher the ROE, the higher the rate of return on investment from the results of the company's equity in gaining profits from the equity owned by the company.

According to (Hidayat, 2019) ROE can be calculated by the formula:

$$
R O E=\frac{E A T}{\text { Equity }}
$$

\section{Price Earning Ratio}

According to (Prasetyorini \& Fitri, 2013) PER shows how much investors are willing to pay for every one rupiah of reported profits. According to (Prasetyorini \& Fitri, 2013) companies with a high growth rate opportunity usually have a high price earning ratio as well, and this shows that the market expects profit growth in the future. According to (Lebelaha \& Saerang, 2016) PER can be calculated by the formula:

$$
P E R=\frac{\text { Price }}{E P S}
$$

\section{Company Value}

According to (Setiawanta, 2016), company value can be interpreted as market value in the capital market. Meanwhile, according to (Utami \& Welas, 2019), company value is the value needed by investors to make investment decisions, which is reflected in the company's market price. selling value of the company or growing value for shareholders, the value of the company will be reflected in the market price of its shares. Firm value is the investor's perception of the company's success rate which is often associated with stock prices. The high share price makes the company value also high. The high company value will make the market believe not only the company's current performance but also the company's future prospects.

According to (Anggriawan, Topowijono, \& Sudjana, 2017) company value can be calculated by the formula:

$$
P B V=\frac{\text { Price }}{\text { Book Value }}
$$

\section{The Effect of Debt to Equity Ratio on Firm Value}

According to (Hidayat, 2019) company assets financed with debt must be utilized optimally, so that the company value will increase, and vice versa.

According to (Musthafa, 2017), if debt increases, it will increase the level of risk, namely paying higher loan interest, expecting a higher rate of return. If the level of risk is high, it will lower the stock price so that the company's value will decrease so that confidence in the company will also decrease.

According to (Utami \& Prasetono, 2016) an increase in DER means an increase in the interest expense borne by the company. With the increase in DER, the company's profitability has decreased. The decline in profitability will have an impact on the decline in the company's share price.

\section{H1 : DER affect Firm Value}

\section{The Effect of Return on Equity on Firm Value}

According to (Languju, Mangantar, \& Tasik, 2016), the higher the ROE the better the position of the owner of the company so that it will lead to better investors' assessment of the company which causes an increase in stock prices and company value.

According to (Ayuningsih, Sunarya, \& Norisanti, 2019), ROE decreases, the possibility that investors tend to avoid buying their shares because they are worried if they do not receive the expected return along with a decline in company value.

According to (Panggabean, Lie, Jubi, \& Astuti, 2018) High profitability generally has a positive correlation with high stock prices which will also have a positive effect on increasing company value.

\section{H2 : ROE affect firm value}




\section{The Effect of Price Earning Value on Firm Value}

According to (Lebelaha \& Saerang, 2016)

Price Earning Ratio is an approach that is more popular among stock analysts and practitioners. The importance of investment for companies because to achieve a company goal through investments made by the company to add value to the company.

(Innafisah, Afifudin, \& Mawardi, 2019) the higher the PER, the higher the price per share of a company and indicates a good company value, so that the company's shares are blue chip in the capital market.

\section{H3 : PER affect firm value}

\section{METHODS}

This research conducted is a deductive research, according to (Sugiyono, 2017) where to answer the problem formulation a concept or theory is used so that a hypothesis can be formulated. The hypothesis is then tested through data collection. The collected data were then analyzed quantitatively by using descriptive statistics.

\section{Population and Sample}

The population used in this study were all mining companies on the Indonesia Stock Exchange from 2014 to 2018. The total population in this study was 44 companies.

samples that are fit to the criteria are 17 companies.

\section{Data Analysis Technique}

The data in this study must first meet the requirements of the classical assumptions before testing the hypothesis to get the best regression model. The data analysis technique in this research is using multiple linear regression

\section{RESULTS AND DISCUSSION Classic Assumption Test Normality Test}

The significant value of the Kolmogorov Smirnov test results is $0.055>0.05$ so that the research data fit to assumption of normality.

\section{Multikolinearity Test}

The multicollinearity test results show that the data in this study does not occur multicollinearity because the tolerance value of all independent variables (DER, ROE and
PER)> 0.10 and the VIF value of all independent variables (DER, ROE and PER) $<10$ which means that there is no correlation. among the independent variables used.

\section{Autocorrelation Test}

Research data does not occur autocorrelation because of the large value du $<$ Dw $<4$ - du or $1.7210<2.049<2.279$

\section{Heteroskedastisity Test}

The data in this study did not occur heteroscedasticity because the Glejser test results showed a significant value of three independent variables (Debt to Equity Ratio, Return on Equity and Price Earning Ratio) greater than the significant value limit of 0.05 .

\section{Multiple Linear Regression Analysis}

Firm Value $=1.019-0.167 \mathrm{DER}+0.002$ ROE + 3.200 PER

A constant of 1.019 states that if the Debt to Equity Ratio, Return on Equity, and Price Earning Ratio are constant or have a value of 0 , the company value is 1.019 units. The Debt to Equity Ratio regression coefficient of -0.167 states that each 1 unit increase in Debt to Equity Ratio will cause a decrease in company value by 0.167 units The Return on Equity regression coefficient of 0.002 states that each 1 unit increase in Return on Equity will lead to an increase in the value of the company by 0.002 units Price Earning Ratio regression coefficient of 3,200 states that each 1 unit increase in Price Earning Ratio will cause an increase in firm value by 3,200 units.

\section{Coefficient of Determination}

The value of Adjusted $\mathrm{R}$ Square shows the number 0.165 which is equal to $16.5 \%$, which means the magnitude of the influence of Debt to Equity Ratio, Return on Equity and Price Earning Ratio on company value in mining companies listed on the Indonesia Stock Exchange for the period 2014-2018 while the remaining $83,5 \%$ is influenced by other variables.

\section{F-Test}

F count $(6,513)>F$ table 2.72 and a significant value of $0.001<0.05$, then $\mathrm{Ha}$ can be accepted, which means that simultaneously the Debt to Equity Ratio, Return on Equity and Price Earning Ratio 
have a significant effect on company value in mining companies listed in Indonesia Stock Exchange for the period 2014-2018.

\section{t-Test}

Debt to Equity Ratio has a value of thitung > -ttable or $-1.842>-1.98969$ and a significant value of $0.069>0.05$, so $\mathrm{Ho}$ is accepted, which means that the Debt to Equity Ratio has no effect on company value in mining companies listed on the Stock Exchange Indonesian Securities for the period 2014-2018.

Return on Equity has a value of tcount> ttable or 3.495> 1.98969 and a significant value of $0.001<0.05$, then $\mathrm{Ha}$ is accepted, which means that Return on Equity has a positive effect on company value in mining companies listed on the Indonesia Stock Exchange in 2014- 2018.

Price Earning Ratio has a value of tcount> ttable or 2.876>1.98969 and a significant value of $0.005<0.05$, then $\mathrm{Ha}$ is accepted, which means that Price Earning Ratio has a positive effect on company value in mining companies listed on the Indonesia Stock Exchange in 2014- 2018.

\section{Discussion}

\section{The Effect of Debt to Equity Ratio on} Firm Value

The results of the research prove that the Debt to Equity Ratio has no effect on company value at mining companies listed on the Indonesia Stock Exchange for the 20142018 period.

The results of this study are also in line with Rahmantio, et al. (2018), namely that DER has no effect on firm value. However, it is different from the research results of (Utami \& Welas, 2019) which state that DER has a negative / significant effect on firm value.

According to Sitanggang (2013: 73), using large amounts of debt will increase the risk borne by shareholders and tend to lower share prices.

The results of this study indicate that the use of debt will not affect the value of the company, this is because mining companies in managing mining resources require a large amount of funds so that investors in deciding their investment decisions have also considered the risks that will occur.

\section{The Effect of Return on Equity on Firm Value}

The research results prove that Return on Equity has a partially positive effect on company value in mining companies listed on the Indonesia Stock Exchange for the period 2014-2018.

The results of this study are also in line with the results of (Setiawanta, 2016) study, namely that ROE has a significant effect in a positive direction on firm value.

According to (Languju, Mangantar, \& Tasik, 2016), the higher the ROE the better the position of the owner of the company so that it will lead to better investors' assessment of the company which causes an increase in stock prices and company value.

From the results of this study indicate that ROE can be used as an indicator in increasing firm value. Investors before deciding on their investment decisions must first observe the ability of a company to generate profits, if the company is able to get profits from year to year, investors are sure that the company can grow and develop well. Thus, the higher the ROE the mining company can obtain, the higher the company value.

\section{The Effect of Price Earning Value on Firm Value}

The results of the research prove that Price Earning Ratio has a partial effect in a positive direction on company value at mining companies listed on the Indonesia Stock Exchange for the period 2014-2018.

The results of this study are also in line with (Lebelaha \& Saerang, 2016), namely the Price Earning Ratio has a significant effect in a positive direction on firm value. However, it is different from the research results of (Languju, Mangantar, \& Tasik, 2016) which state that PER has no significant effect on firm value.

According to (Lebelaha \& Saerang, 2016) Price Earning Ratio is an approach that is more popular among stock analysts and practitioners. The importance of investment for companies because to achieve a company's goals through investments made by companies to add value to the company.

Price Earning Ratio can be used as an indicator to assess how good the value of the company is because for investors if the higher the Price Earning Ratio, the expected profit growth rate will also increase. This is a positive signal for investors which ultimately affects the increase in company value. 


\section{CONCLUSIONS}

Partially the Debt to Equity Ratio has no effect on firm value at mining companies listed on the Indonesia Stock Exchange for the period 2014-2018

Partially Return on Equity has a positive effect on company value in mining companies listed on the Indonesia Stock Exchange for the 2014-2018 period

Partially Price Earning Ratio has a positive effect on firm value at mining companies listed on the Indonesia Stock Exchange for the period 2014-2018

Simultaneously the Debt to Equity Ratio, Return on Equity and Price Earning Ratio have an effect on company value in mining companies listed on the Indonesia Stock Exchange for the period 2014-2018

\section{REFERENCES}

Anggriawan, F., Topowijono, T., \& Sudjana, N. (2017). The Influence of Capital Structure on Firm alue (Study on Food and Beverage sub Sector Companies Listing on the Indonesia Stock Exchange year 2011-2015). Business Administration Journal , 105-114.

Ayuningsih, S. D., Sunarya, E., \& Norisanti, N. (2019). Analysis Relatedity ROE \& EPS to the Value of Company PT. Astra Agro Lestari Tbk. Journal Business \& Management , 65-71.

Hidayat, W. (2019). The Influence of Company Size, ROE and Leverage on Firm Value in Manufacturing Companies in Indonesia. In Forum Economi , 67-75.

Innafisah, L., Afifudin, A., \& Mawardi, M. C. (2019). The Effect of Earning Per Share (EPS), Price Earning Ratio (PER) and Dividend Payout Ratio (DPR) on the Value of Property and Real Estate Companies Listed on the Indonesia Stock Exchage (IDX) for the 2014-2017 period. Accounting Research Scientific Journal , 37-52.

Jusuf, J. (2016). Credit Analysis for Account Officers. Jakarta: PT. Gramedia Pustaka Utama.

Languju, O., Mangantar, M., \& Tasik, H. H. (2016). Effect of ROE, Company Size, PER and Capital Structure on Firm
Value Property and Real Estate are Listed on The Indonesia Stock Exchage. Jurnal Berkala IImiah Efisiensi , 387-398.

Lebelaha, D. L., \& Saerang, I. S. (2016). The Influence of PER, DER and DPR on the Value of BUMN Companies listed on The Indonesia Stock Exchange for the period 2011-2014. Jurnal Berkala IImiah Efisiensi , 376-386.

Musthafa. (2017). Financial Management. Yogyakarta: CV. Andi.

Panggabean, B. F., Lie, D., Jubi, J., \& Astuti, A. (2018). The Effect of Solvency and Prifitability on Firm Value in Coal Mining Sub Sector Companies Listed on the Indonesia Stock Exchange. Financial : Accounting Journal , 65-72.

Prasetyorini, F., \& Fitri, B. (2013). The Influence of Company Size, Leverage, PER and Profitability to Firm Value. Management Science Journal , 183-196.

Setiawanta, Y. (2016). Profitability, Liquidity and Company Value (Property and Real Estate Industry Listed at PT. IDX in 2011-2014). Research Journal Economic and Business, 151-163.

Sugiyono. (2017). Qualitative and Quantitative Research Methods $R \& D$. Bandung: PT. Alfabeta.

Utami, P., \& Welas, W. (2019). The Influence of Current Ratio, Return on Asset, Total Asset Turnover and DER on Firm Value (Empirical Study of Manufacturing Companies in the Property and Real Estate sub Sector Listed on the Indonesia Stock Exchange 2015-2017) Period. Journal Accounting and Finance , 57-76.

Utami, R. B., \& Prasetono, P. (2016). Analysis of The Effect of TATO, WCTO and DER on Firm Value with ROA as an Intervening Variable (Study of Manufacturing Companies Listed on The Indonesia Stock Exchange 2009-2013 Period. Dipenogoro Journal of Management , 105-118. 


\section{List of Tables}

Table 1. Normality Test (Arial 9 Bold, Sentence case)

One-Sample Kolmogorov-Smirnov Test

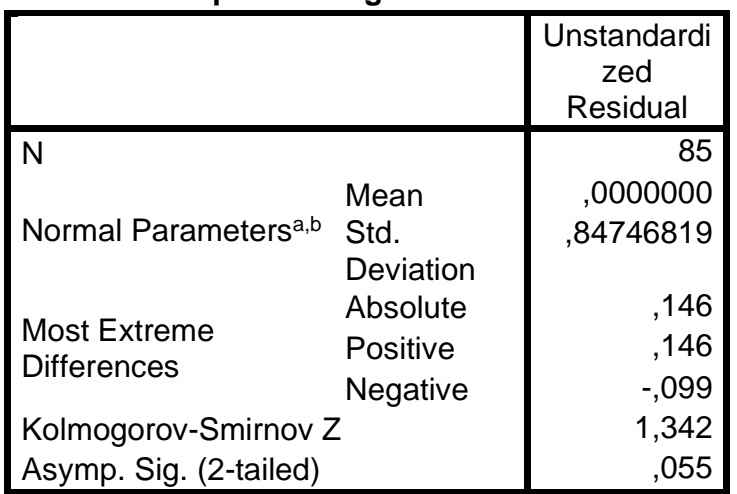

a. Test distribution is Normal.

b. Calculated from data.

Table 2. Multikolinearity Test

Coefficients $^{a}$

\begin{tabular}{|rr|r|r|}
\hline \multirow{2}{*}{ Model } & \multicolumn{2}{|c|}{ Collinearity Statistics } \\
\cline { 3 - 4 } & & Tolerance & \multicolumn{1}{c|}{ VIF } \\
\hline \multirow{2}{*}{1} & INVERSX1 &, 989 & 1,011 \\
& INVERSX2 &, 858 & 1,166 \\
& INVERSX3 &, 865 & 1,156 \\
\hline
\end{tabular}

a. Dependent Variable: INVERSY

Table 3. Autocorrelation Test

Model Summary

\begin{tabular}{|c|c|c|c|c|c|}
\hline $\begin{array}{c}\text { Mo } \\
\text { del }\end{array}$ & $\mathrm{R}$ & $\begin{array}{c}\mathrm{R} \\
\text { Squa } \\
\text { re }\end{array}$ & $\begin{array}{c}\text { Adjusted } \\
\mathrm{R} \\
\text { Square }\end{array}$ & $\begin{array}{c}\text { Std. } \\
\text { Error of } \\
\text { the } \\
\text { Estimate }\end{array}$ & $\begin{array}{c}\text { Durbin- } \\
\text { Watson }\end{array}$ \\
\hline 1 &, $441^{\mathrm{a}}$ &, 194 &, 165 &, 86302 & 2,049 \\
\hline
\end{tabular}

a. Predictors: (Constant), INVERSX3, INVERSX1, INVERSX2

b. Dependent Variable: INVERSY
Table 4. Heteroskedastisity Test

Coefficients $^{a}$

\begin{tabular}{|c|r|r|r|r|r|}
\hline Model & \multicolumn{2}{|c|}{$\begin{array}{c}\text { Unstandardized } \\
\text { Coefficients }\end{array}$} & $\begin{array}{c}\text { Standardiz } \\
\text { ed } \\
\text { Coefficient } \\
\text { s }\end{array}$ & Sig. & \\
\cline { 2 - 4 } & \multicolumn{1}{|c|}{$\mathrm{B}$} & Std. Error & \multicolumn{1}{c|}{ Beta } & \\
\hline (Constant) &, 552 &, 146 & & 3,768 &, 000 \\
INVERSX1 &,- 068 &, 057 &,- 128 & $-1,194$ &, 236 \\
INVERSX2 &, 001 &, 000 &, 220 & 1,911 &, 060 \\
INVERSX3 & 1,274 &, 701 &, 209 & 1,817 &, 073 \\
\hline
\end{tabular}

a. Dependent Variable: ABSUT

Table 5. Multiple Linear Regresion

Coefficients $^{a}$

\begin{tabular}{|c|c|c|c|}
\hline \multirow{2}{*}{\multicolumn{2}{|c|}{ Model }} & \multicolumn{2}{|c|}{ Unstandardized Coefficients } \\
\hline & & $B$ & Std. Error \\
\hline \multirow{4}{*}{1} & (Constant) & 1,019 & ,232 \\
\hline & INVERSX1 &,- 167 & ,091 \\
\hline & INVERSX2 &, 002 &, 001 \\
\hline & INVERSX3 & 3,200 & 1,113 \\
\hline
\end{tabular}

a. Dependent Variable: INVERSY

Table 6. Coefficient Determination

Model Summary

\begin{tabular}{|c|r|r|r|r|}
\hline Model & $\mathrm{R}$ & $\begin{array}{c}\mathrm{R} \\
\text { Square }\end{array}$ & $\begin{array}{c}\text { Adjusted } \mathrm{R} \\
\text { Square }\end{array}$ & $\begin{array}{r}\text { Std. Error of } \\
\text { the Estimate }\end{array}$ \\
\hline 1 &, $441^{\mathrm{a}}$ &, 194 &, 165 &, 86302 \\
\hline
\end{tabular}

a. Predictors: (Constant), INVERSX3, INVERSX1, INVERSX2

Table 7. F Test

ANOVA $^{a}$

\begin{tabular}{|l|r|r|r|r|r|}
\hline \multicolumn{1}{|c|}{ Model } & $\begin{array}{c}\text { Sum of } \\
\text { Squares }\end{array}$ & Df & $\begin{array}{c}\text { Mean } \\
\text { Square }\end{array}$ & F & Sig. \\
\hline $\begin{array}{l}\text { Regress } \\
\text { ion }\end{array}$ & 14,553 & 3 & 4,851 & 6,513 &, $001^{\mathrm{b}}$ \\
$\begin{array}{l}\text { Residua } \\
\text { I }\end{array}$ & 60,329 & 81 &, 745 & & \\
Total & 74,882 & 84 & & & \\
\hline
\end{tabular}

a. Dependent Variable: INVERSY

b. Predictors: (Constant), INVERSX3, INVERSX1, INVERSX2 
Tabel 8. T-Test

Coefficients $^{a}$

\begin{tabular}{|rr|r|r|}
\hline \multicolumn{2}{|c|}{ Model } & \multicolumn{1}{c|}{$\mathrm{t}$} & \multicolumn{1}{l|}{ Sig. } \\
\hline & (Constant) & 4,383 &, 000 \\
1 & INVERSX1 & $-1,842$ &, 069 \\
& INVERSX2 & 3,495 &, 001 \\
& INVERSX3 & 2,876 &, 005 \\
\hline
\end{tabular}

a. Dependent Variable: INVERSY

\section{List of Figures}

Figure 1. Model Test

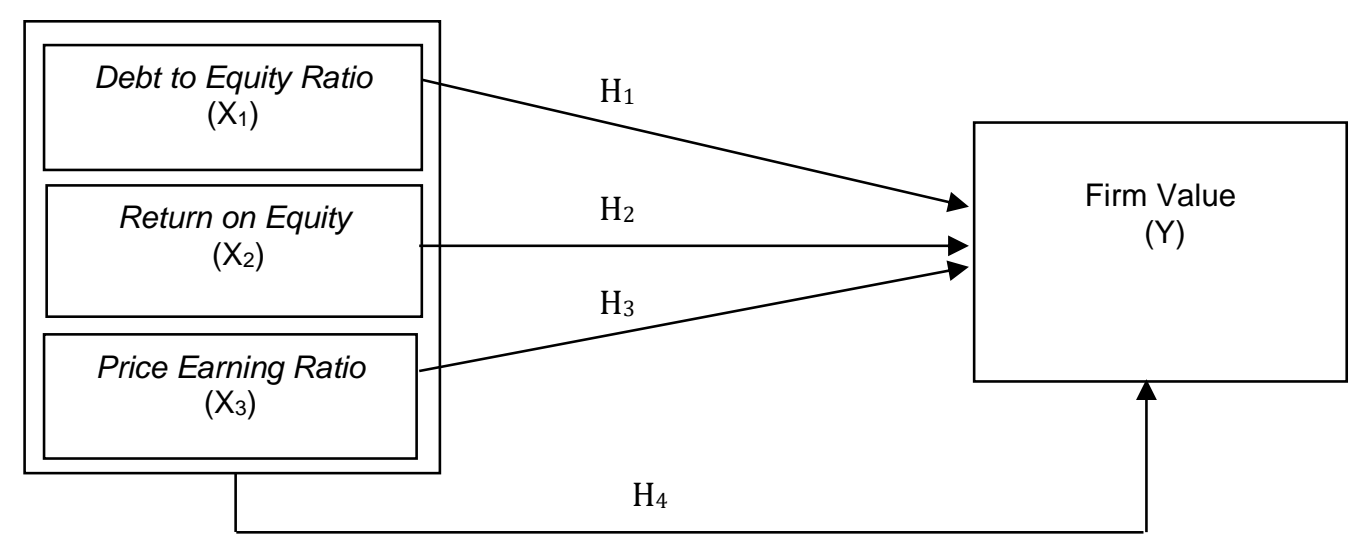

